\title{
antibodies
}

ISSN 2073-4468

www.mdpi.com/journal/antibodies

Review

\section{Invariant Natural Killer T Cells}

\section{Antonella Cianferoni}

Divisions of Allergy and Immunology, Department of Pediatrics, The Children's Hospital of Philadelphia, Perelman School of Medicine, University of Pennsylvania, Philadelphia, PA 19104, USA; E-Mail: cianferonia@email.chop.edu; Tel.: +1-267-426-7831; Fax: +1-215-590-4529

Received: 8 November 2013; in revised form: 13 December 2013 / Accepted: 18 December 2013 / Published: 23 December 2013

\begin{abstract}
Invariant Natural killer T cell (iNKT cells) are a subset of T cells, which are narrowly defined as a $\mathrm{T}$ cell lineage expressing a semi-invariant CD1d-restricted $\mathrm{T}$ cell Receptors (TCRs) composed by V $\alpha 24-J \alpha 18 / V \beta 11$ in human, and V $\alpha 14-J \alpha 18 / V \beta 8, V \beta 7$, and V $\beta 2$ in mouse. Unlike conventional $\mathrm{T}$ cells which recognize peptides bound to highly polymorphic major histocompatibility complex (MHC) class I and II molecules, iNKT cells recognize lipid antigens, such as glycolipids, presented by CD1d, a non-polymorphic non-classical MHC class I molecule. Lipids derived from microbes, tumors, and allergens, as well as self lipids have been shown to be able to activate iNKT cells. Early on, in an immune response, ligation of the iNKT cell TCR leads to rapid and copious secretion of prototypical Th1 and Th2 cytokines. Moreover, like NK cells, iNKT cells express cytotoxic granules, such as perforin and granzyme that polarize upon activation of TCR and are able to kill target cells. Therefore iNKT cells are a very interesting subset of T cells that may bridge the innate and adaptive immune systems. Indeed, iNKT cells can mount specific responses to antigen with cytokine production and cytotoxic activity, however, their TCR evolved to recognize different glycolipid antigens in a conserved manner and to perform innate-like rather than adaptive functions. iNKT cells are now recognized as important players in atopic, autoimmune, infectious diseases, and cancer.
\end{abstract}

Keywords: invariant Natural killer cells; iNKT cells; immunology; cytokines; lipids; sphingolipids; CD1D; allergy; autoimmunity; infectious diseases; cancer 


\section{Introduction}

Recent studies have shown that a subset of $\mathrm{T}$ cells responsive to lipid may play a central role in regulating human immune responses. These cells, known as Natural killer T cell (NKT cells), are a subset of T cells, which are narrowly defined as a T cell lineage expressing NK lineage receptors (i.e., NK1.1, Ly-49) in addition to semi-invariant CD1d-restricted $\alpha \beta \mathrm{T}$ cells receptors (TCRs). In mice, more than $80 \%$ of these NKTs have TCRs that express V $\alpha 14-\mathrm{J} \alpha 18 / \mathrm{V} \beta 8, \mathrm{~V} \beta 7$, and V $\beta 2$, and they are called invariant NKT (iNKT cells) or Type I NKT cells. They all recognize a marine sponge derived glycolipid called $\alpha$-galactosylceramide ( $\alpha$ GalCer) [1]. The remaining $20 \%$ of NKT cells express a collection of rare but recurrent $\mathrm{V} \alpha 3.2-\mathrm{J} \alpha 9 / \mathrm{V} \beta 8, \mathrm{~V} \alpha 8 / \mathrm{V} \beta 8$, and other TCRs, and are called Type II NKT cells [1]. The best known and more studied NKTs are the iNKT cells (Type I NKT cells). In human iNKT cells express V $\alpha 24-\mathrm{J} \alpha 18 / \mathrm{V} \beta 11$ and are also the most extensively studied type. However, recent studied have showed that iNKT cells may not represent the majority of CD1d reactive cells in humans [2,3]. Given that Type II NKT cells seem to have similar characteristics to type I, in terms of cytokine secretion and function, but are for the most part poorly characterized in term of frequency, specific ligands, and role in many diseases, the present review will focus on iNKT cells (type I NKT cells).

Unlike conventional $\mathrm{T}$ cells, which recognize peptides bound to highly polymorphic major histocompatibility complex (MHC) class I and II molecules, iNKT cells recognize lipid antigens presented by CD1d, a non-polymorphic non-classical MHC class I molecule [1].

Early on, in an immune response, ligation of the iNKT cell TCR leads to rapid and copious secretion of prototypical Th1 and Th2 cytokines [1,4].

Moreover like NK cells, iNKT cells express cytotoxic granules such as perforin and granzyme that polarize upon activation of TCR and are able to kill target cells such as APCs or T reg $[5,6]$.

Therefore, iNKT cells are a very interesting subset of $\mathrm{T}$ cells that may bridge the innate and adaptive immune systems. Indeed, iNKT cells can mount specific responses to antigen with cytokine production and cytotoxic activity however their TCR evolved to recognize different glycolipid antigens in a conserved manner and to perform innate-like rather than adaptive functions $[1,7]$.

\section{2. iNKT Cell-TCR}

Like any T cell TCR, the $\alpha$ - and $\beta$-chains that compose the iNKT cells TCR, are each subdivided into a variable (V) domain and a constant $(\mathrm{C})$ domain. The $\alpha$-chains $\mathrm{V}$ domains are encoded by $\mathrm{V}(T R A V)$ and joining $(\mathrm{J}$; TRAJ) gene segments, whereas $\beta$-chain $\mathrm{V}$ domains are encoded by $\mathrm{V}$ $(T R B V)$, diversity $(\mathrm{D} ; T R B D)$, and $\mathrm{J}(T R B J)$ genes. Crystallographic studies of the V $\alpha 24-\mathrm{V} \beta 11$ NKT TCR- $\alpha$ GalCer-CD1d have shown that NKT TCR is relatively rigid when it is bound to $\alpha$ GalCer-CD1d, and that such interaction is almost identical to the one observed between the mouse type I V $\alpha 14-\mathrm{V} \beta 8.2$ NKT TCR and $\alpha$ GalCer-CD1d [8]. These characteristics reveal that the iNKT cell TCR functions like a pattern-recognition receptor (i.e., an innate-like, germline-encoded receptor that interacts in a conserved manner with its ligands) [8].

However the $\alpha \beta \mathrm{V}$ domains have three complementarity-determining regions (CDRs) that form the antigen-binding site of the TCR. The CDR1 and CDR2 loops are very conserved as they are germline-encoded by the variable (V) $\alpha$ and $\beta$ genes, on the other hand, the CDR3b region includes 
$\mathrm{V} \beta-\mathrm{D} \beta-\mathrm{J} \beta$ joints, where the various combinations of $\mathrm{V}, \mathrm{D}$, and $\mathrm{J}$ gene segments and random non-templated alterations at the $\mathrm{V}(\mathrm{D}) \mathrm{J}$ gene junctional boundaries create the greatest diversity within the CDR3 loops [9].

TCR $\alpha$-chain elements contribute to $\alpha$-linked glycosphingolipid specificity, whereas TCR $\beta$-chains confer heterogeneous additional reactivities. The variations in TCR $\beta$-chain usage modulate TCR affinity, which indirectly contributes to the preferential recognition of some antigens $[9,10]$. Indeed, the CDR1 and 3 on the $\alpha$-chain appear to bind the glycolipid antigen. On the other hand, V $\beta 11$ CDR3 $\beta$ has been shown to be dispensable for $\alpha$ GalCer recognition [8,9,11-13]. Hence, is logical to infer that CDR3 $\beta$ sequences in iNKT cells could mediate iNKT cells subset specificity for different CD1dantigens [14].

\section{CD1d}

INKT cells recognize lipid antigens presented by CD1d, a non-polymorphic non-classical MHC class I molecule. CD1 molecules are b2-microglobulin-associated surface glycoproteins that bear significant structural similarity to MHC class I molecules [15]. In humans, the CD1 family consists of five members, designated CD1a, CD1b, CD1c, CD1d, and CD1e. Based on homology relationships and the details of their expression and function, CD1a, -b, -c, and -e are classified as group 1 CD1 molecules $[1,16]$.

CD1d composes a separate group, and is the only member of the group 2 CD1 molecules [17]. Both, group 1 and group 2 CD1 molecules, are lipid-binding proteins that are expressed on specialized antigen-presenting cells (APC), including dendritic cells (DCs,) where they perform the role of presenting foreign and self-lipids and glycolipids to $\mathrm{T}$ cells. In marked contrast to the highly polymorphic MHC-encoded protein antigen-presenting molecules, CD1 proteins show extremely limited polymorphism between individuals of a given species [18].

The group 1 CD1 molecules have been characterized most extensively in humans and have been demonstrated to present microbial lipid antigens and certain self-lipids to a diverse group of T cells [19].

Group 2 CD1 molecules (i.e., CD1d) have been identified in mice and humans as the critical antigen-presenting molecule that controls the development and function of iNKT cells $[17,19]$.

\section{4. iNKT Cell Development}

INKT cells and CD1d are conserved thought the evolution; hence they are very similar in mice and humans. In mouse, they represent $\sim 0.5 \%-1 \%$ of the $\mathrm{T}$ cell population in the thymus, blood and peripheral lymph nodes, $\sim 2.5 \%$ of $\mathrm{T}$ cells in the spleen, mesenteric, and pancreatic lymph nodes, and up to $30 \%$ of T cells in the liver. In humans, iNKT cells appear to be overall $\sim 10$-times less frequent, although the tissue distribution is less well-studied than in mice and it is largely unknown $[1,20]$.

However, both in human and mice, the peripheral blood iNKT cell levels vary considerably between subjects, ranging from $0.01 \%$ (considered the lowest detectable level) to up to nearly $1 \%$ in humans $[1,20]$. Such a variability in numbers of circulating NKT is still unexplained, but it appears to be to be a stable phenotype tightly controlled at the genetic levels [1,20]. Moreover recent data suggest that there are some sex-based differences in iNKT cells, probably due to the effects of sex hormones on these cells. Indeed higher numbers are more commonly observed in women [21] and iNKT cells in female mice produce higher levels of IFN- $\gamma$ than in their male counterpart, due to their higher estradiol 
levels [22]. It is not known if this observed sex bias is due to the fact that an X-linked gene controls iNKT cell development [21]. Indeed iNKT cell development happens in thymus in both mice and humans [23,24]; depends on thymocyte-thymocyte interactions; requires the presence of Src kinase Fyn $[25,26]$ and the adaptor protein named signaling lymphocytic activation molecule (SLAM)-associated protein (SAP) [27-29]. SAP binds to the SLAM family receptors, to which it recruits Fyn, thus, induces SLAM phosphorylation and activation of downstream phosphotyrosine signaling [30]. Even if SAP is present in both T cell and iNKT cells, Nichols et al. [27] showed that SAP expression is essential for iNKT- but not T- cell development.

For a normal development iNKT cells also require GATA3 and T-bet transcription factors, but not NF-kB [31]. Indeed, GATA3 by inducing Thpok expression is necessary to maintain CD4 and terminate CD8 expression [32,33]. If TCR signaling is a prerequisite for early stage development, IL-15 signaling is essential for expansion and maturation at later stages, as it regulates T-bet and T-bet dependent factors (such as IFN- $\gamma$, granzyme A and C) expression [34]. Finally, TNF receptor associated factor 3 (TRAF3) plays a critical role in the transition between the TCR- and IL-15- dependent developmental stages. Indeed, TRAF3-deficient iNKT cells in CD4(Cre)TRAF3(flox/flox) (T-TRAF3(-/-)) mice exhibit defective up-regulation of T-bet and CD122, two critical molecules for IL-15 signaling [35].

\section{Lipid Antigens Able to Activate NKT Cells}

iNKT cells have been shown to play a role in many diseases such as microbial infection, autoimmune disease, allergic disease, and cancer [24,36-46]. iNKT cells are activated by foreign and self antigen lipids [47]. The best-characterized molecules that appear to be able to stimulate iNKTcells are glycolipids (GL), which can have a ceramide (glycosphingolipids) or a diacil glycerol (DAG) backbone (glycosyl diacylglycerolipids). More recently some other lipids, such as sphingolipids (SL) have been shown to be weak activator of NKT cells $[24,48]$.

All mouse Va14 and human Va24 iNKT cells recognize the marine sponge-derived aGalCer [49], a $\alpha$-branched galactosylceramide, which was slightly modified to achieve optimal efficacy to develop the compound known as KRN7000. $\alpha \mathrm{GalCer}$ is a specific and potent lipid antigen and was firstly described, in 1997, by Kawano et al. [49,50]. The crystal structure of human CD1d in complex with synthetic $\alpha$ GalCer shows the lipid nestled tightly in the CD1d binding groove $[13,51,52]$. iNKT cells are capable of recognizing both the group head and the length of the lipid antigens, ensuring specificity of antigen recognition [11,53,54]. The affinity of interaction between CD1d- $\alpha$ GalCer and the mouse Va14Vb8.2 TCR is one of the highest ever recorded for natural TCR/ligand pairs with a $\mathrm{Kd} \sim 10 \mathrm{nM}$, due to the fact that the ligand has a slow off rate combinations, even if it may be 10 times less strong in humans [8,51]. $\alpha \mathrm{GalCer}$ has been a precious tool to study iNKTcells and has provided evidences that the semi-invariant TCRs of iNKT cells has evolved to recognize $\alpha$-anomeric glycosphingolipids with high affinity. Indeed more than $95 \%$ of cloned mouse and human iNKT cells recognize $\alpha$ GalCer, irrespective of their variable CDR3 $\beta$ sequence, with a high degree of conservation among species. Thus, it is not surprising that the mouse CD1d- $\alpha$ GalCer tetramers stain human and nonhuman primate iNKT cells. 
In the last decade there has been extensive research to find lipids present in the humans or microbes able to stimulate iNKT cells.

Members of $\alpha$-proteobacteria, such as sphingomonas, have been shown to express glycosphingolipids closely related to $\alpha$ GalCer. Those glycolipids substitute for lipopolysaccharide (LPS) in their cell wall, as sphingomonas do not produce LPS [52]. Such glycolipids have only one sugar, a galacturonic acid (GalA), or a glucuronic acid (GlcA) $\alpha$-anomerically linked to the ceramide backbone GSLs and they are able to activate iNKT cells with a strength similar to the $\alpha$ GalCer [55]. Not surprisingly, iNKTcells have been shown to be essential in clearing sphingomonas infections. Other glycolipids (i.e., B. burgdorferi glycolipid-II (BbGL-II), glucosyl-diacylglycerol (Glc-DAG)), able to activate iNKT cells have been isolated from the spirochete Borrelia burgdorferi and S. pneumonia [56,57].

Many other bacteria produce glycolipids and some have shown a limited capacity to activate iNKT cells. For example, phosphatidylinositol mannosides (PIMs), from Mycobacterium bovis, bacillus Calmette-Guerin, lipophosphoglycan from Leishmania donovani, a cholesterol-containing glycolipid from Helicobacter pylori, and an antigen from Chlamydia muridarum were reported to activate iNKT cells [58-62]. Most of the above mentioned compounds however only activate a minority of the iNKT cells and are considered weak ligands.

Other weak ligands of iNKT cells have been identified in food allergens. Some of those ligands SL and are found in many foods, including milk, soy, and egg [63-65]. It is estimated the average individual consumes approximately 0.3 to 0.4 grams of SL every day [63]. Interestingly, the foods richest in SL (i.e., dairy products, soybeans and egg) are the most common triggers of early food allergy in children [66]. SLs, present in food, include sphingomyelin, ceramides and some glycosphingolipids. Dietary SLs are not thought to contribute much to the daily energy needs of humans, nor do they appear to be "essential" nutrients, although this has not yet been explored in the context of disease. Nonetheless, given their biological activities, SLs can be categorized as "functional" components of food. Food-SL inhibit colorectal cancer and in mice, they increase both Th1- and Th2-cytokine secretion in the small intestine by a mechanism that has not yet been clarified [63,67].

Two different independent groups have demonstrated that milk has lipids that are able to activate NKT cells. Jyonouchy et al. [24,40] demonstrated that iNKT cells could be activated by a mix of milk derived sphingomyelin, which had phosphocholine residue at the 1-OH-position and different tail length with the main component being $\mathrm{C} 23: 0$ and the remainder C16:0, C18:0, C20:0, C20:4, C22:0, $\mathrm{C} 24: 0, \mathrm{C} 24: 1$. Brennan et al. [47] showed instead that a milk-derived glucopyranosylceramide ( $\beta$-GlcCer) was an iNKT cell activator. Interestingly, the same authors found that $\beta$-GlcCer was also a self antigen in mouse and human and, was a potent iNKT cell stimulator. Its activity depended on the composition of the $\mathrm{N}$-acyl chain and accumulated during infection and in response to Toll-like receptor agonists, contributing to iNKT cell activation. The author speculated that that recognition of $\beta$-GlcCer could translate innate danger signals into iNKT cell activation. The authors also demonstrated that glycolipids attached to the lipid moiety by a $\beta$-anomeric linkage rather than the $\alpha$-anomeric linkage found in $\alpha$-GSLs could still activate NKT cells. This is an important discovery to understand how self lipid can activate iNKT cells in animals. Indeed mammalian cells are thought not to produce $\alpha$-GSLs.

Finally, iNKT cells have been shown also to release large amount of IFN- $\gamma$ when activated by a combination of self-antigen recognition and IL-12 from antigen-presenting cells (APCs), induced [68]. 
Production of IL-12 by APCs was induced through recognition of fungal cell wall $\beta-1,3$ glucans by Dectin-1, $\alpha$ C-type lectin receptor that binds this glycan [68].

\section{6. iNKT Cell Derived Cytokines}

Early on, in an immune response, ligation of the iNKT cell TCR leads to rapid and copious secretion of prototypical Th1 and Th2 cytokines, such as IFN- $\gamma$ and IL-4, and in some cases, GM-CSF, IL-10, IL-13, TGF- $\beta$, to cite a few $[1,69]$. Similar to conventional T cells, the cytokine profile of iNKTcells in some diseases or mouse models is polarized to a Th1 or Th2 pattern [70]. iNKT cells appear to be an important source of Th2 cytokines [7]. Interestingly, co-administration of exogenous protein antigen with $\alpha$ GalCer, results in an increase in Th2-cell-associated sensitization of mice to these antigens [71]. Similarly, activation of iNKT cells in vivo with $\alpha \mathrm{Gal}$ or other glycolipid antigens results in a rapid increase in total serum IgE [72]. In addition, Va14-Ja18-transgenic mice, which express more iNKT cells than wild-type mice, have higher serum concentrations of the Th2-cellassociated immunoglobulins IgG1 and IgE [73]. Together these data suggest that iNKT cells, when appropriately stimulated, favor a Th2 response, $\operatorname{IgE}$ production and subsequent sensitization. In particular, iNKT cells Th-2 polarization appears to play a critical role in the development of asthma as adoptive transfer experiments show that the production of IL-4 and IL-13 by iNKT cells is at least one component of their essential role in promoting airways hyper reactivity (AHR) [74] and severe persistent asthma [75]. INKT cells polarized to produce IL-4 in some animal model appear to be able to control autoimmune diabetes and Experimental Autoimmune Encephalomyelitis (EAE) [76-78]. On the other hand, iNKT cells Th1 polarization appears to be important for cancer surveillance [70].

Finally, iNKT cells, expecially those expressing foxp3 [79], may have some direct regulatory properties. Indeed, peripheral and cord blood iNKT cells pretreated with TGF- $\beta$ and rapamycin expressed Foxp3, and were able to suppress the proliferation of conventional autologous and heterologous CD4+ $\mathrm{T}$ cells, in a cell contact-dependent and antigen-independent manner [80]. Moreover, iNKT cells may promote $\mathrm{T}$ reg development. Indeed in a mouse model iNKT cells were found to play an indispensable role in oral tolerance by inducing $\mathrm{T}$ reg, and clonally deleting antigenspecific CD4+ T cells [81].

Despite the well characterized ability of iNKT cells to produce high levels of both Th1 and Th2 cytokines, little is known about how iNKT cells control the transcription of Th1/Th2 cytokines. Some recent studies showed that CD4+ iNKT cells are highly enriched for Th2 cytokine expression compared with CD4-iNKT cells and NFAT2 appeared to be important for IL-4 iNKT cell expression, whereas GATA3 and Stat6 appeared to play a marginal role in suggesting that GATA-3, and Stat6 have surprisingly different roles in iNKT cells than in conventional T cells [82]. On the other hand, mice studies have shown that GATA3 may be important in IL-4 production from iNKT cells. Indeed in sap deficient mice iNKT cells did not produce significant levels of IL-4 or IFN- $\gamma$. The reduction in cytokine production correlated with the near absence of GATA-3 and T-bet, but ectopic expression of GATA-3 partially restored IL-4 production by the iNKT cells [31]. 


\section{7. iNKT Cell Cytotoxicity}

Like NK cells, iNKT cells express cytotoxic granules such as perforin and granzyme that polarize upon activation of TCR and are able to kill target cells such as activated, infected, and malignant cells $[5,6]$. Moreover, iNKT cell cytotoxicity increases local inflammation, is involved in anti-tumor defense and may promote the immune-disregulation by killing $\mathrm{T}$ reg cells $[6,7,41,83,84]$. In some infections, such as Leishmania, their cytotoxicity may be essential to fight the infection. Indeed dendritic cells infected with $L$. infantum up-regulate CD1d cell surface expression and consequently can be efficiently recognized and killed by iNKT cells [85]. Interestingly, such cytotoxicity is increased by IL-4 in an autocrine fashion [83]. Das, R., et al. recently demonstrated that immunological synapse formation and TCR mediated cytotoxicity depends on SAP [86].

\section{8. iNKT Cells Role in Disease}

Several studies have been published on the role of iNKT cells in infectious diseases, cancer, allergy, and autoimmunity.

\section{1. iNKT Cells in Allergic Diseases}

In a mouse model of oral tolerance to ovalbumin (OVA), iNKT cells were found to play an indispensable role in oral tolerance by inducing regulatory $\mathrm{T}$ cells, and clonally deleting antigenspecific CD4+ T cells [81]. On the other hand, in a mouse model of eczema, iNKT cells appeared irrelevant [87].

Although iNKT cells are not required for the induction of TH2-cell-associated immune responses, they have been shown to influence TH2-cell-biased responses as they are an important source of Th2 cytokines [7]. Indeed, investigators have found that co-administration of exogenous protein antigen with $\alpha$-GalCer, which specifically activates iNKT cells and can induce the production of both IL-4 and IFN $\gamma$, results in an increase in TH2-cell-associated sensitization of mice to these antigens [71]. Similarly, activation of iNKT cells in vivo with $\alpha$-GalCer or other glycolipid antigens results in a rapid increase in total serum IgE [72]. In addition, Va14-J $\alpha 18$-transgenic mice, which express more TCRs that contain this invariant $\alpha$-chain than do wild-type mice and therefore contain more NKT cells, have higher serum concentrations of the TH2-cell-associated immunoglobulins, IgG1, and IgE [73].

Recently, our group has shown that iNKT cells stimulated by milk-derived sphingolipid may be implicated in the pathogenesis of food allergy. Indeed, in children with IgE mediated food allergy to cow's milk, iNKT cells were reduced in number and exhibit a Th2-bias in response to $\alpha \mathrm{GalCer}$ and milk-sphingolipid stimulation. These data suggest a potential role for iNKT cells in food allergy [24]. Moreover, our group found that children with active Eosinophilic Esophagitis had significantly fewer peripheral blood iNKT cells with a greater Th2-cytokine production after to $\alpha \mathrm{Gal}$ and milk-shingolipid stimulation compared to iNKT cells derived from children with controlled Eosinophilic esophagitis or healthy controls [40]. Children with active eosinophilic esophagitis had increased iNKT cells levels in esophageal biopsies compared to children with controlled eosinophilic esophagitis, suggesting the iNKT cell may migrate from the peripheral blood to the site of active esophageal eosinophilic inflammation [40]. This could explain how milk could contribute to local inflammation in eosinophilic 
esophagitis. Indeed, eosinophilic esophagitis is an atopic disease characterized by eosinophilic inflammation in which dietary antigens (in particular, milk) play a major role. However, it is not clear how milk can induce such inflammation as the vast majority of children who respond to a milk free diet have no specific IgE against milk, and patch skin test to milk show no delayed inflammation to milk [40].

If iNKT cells are involved in the development of asthma, it is still subject of controversy. In one paper that has never been reproduced by other groups, iNKT cells producing Th2 cytokines represented about 60 percent of the pulmonary CD4+CD3+ cells in patients with moderate-to-severe persistent asthma [75]. Mice lacking iNKT cells, because of gene knockouts in TCRAJ18 locus (required for the invariant TCR $\alpha$ chain expressed by these T cells) or the CD1D locus (required for thymic positive selection of developing iNKT cells), show markedly reduced airway inflammation and asthma following challenge with the sensitizing protein antigen $[42,74,88]$. Based on adoptive transfer experiments, it seems that the production of IL-4 and IL-13 by iNKT cells is at least one component of their essential role in promoting AHR [74]. When directly activated by glycolipid antigens, iNKT cells induce the development of AHR, in the complete absence of conventional $\mathrm{CD} 4^{+} \mathrm{T}$ cells and adaptive immunity [72]. The requirement for iNKT cells in the development of AHR is curious, because antigen-induced TH2-cell responses and antigen-specific TH2 cells develop and respond normally in CD1d-deficient mice and in Ja18-deficient mice, but these responses are clearly insufficient for the induction of AHR [89-91].

Interestingly, mice infected with Sendai virus develop chronic lung disease and airway hypersensitivity similar to asthma and chronic obstructive pulmonary disease (COPD) in humans and such chronic manifestation was dependent IL-13 from macrophages and iNKT cells [92]. Macrophages and iNKT cells depletion reduced chronic disease manifestation. These data suggest that iNKT cells participate in the pathogenesis of chronic inflammatory lung disease [92].

\section{2. iNKT Cells in Autoimmune Diseases}

It has been suggested that iNKT cells may play a role both in protection and pathogenesis of autoimmunity [44,74,75,93-95]. Indeed, iNKT cells seem to promote atherosclerosis [93], Th-2 colitis in mice [96], whereas have a suppressive role in some models of Diabetes Type I [97], Lupus [98,99], cancer, delayed type hypersensitivity [93,94], in anterior chamber-associated immune deviation [100].

In mice in the model of immune privilege in the eye, known as anterior chamber-associated immune deviation (ACAID), DC derived MIP-2, a functional murine homolog of human IL-8, appeared essential for iNKT cell recruitment to the spleen, where they induced $\mathrm{T}$ reg through IL-10/TGF $\beta$ production [101,102].

Nonobese diabetic (NOD) mice, which develop Type I diabetes as a result of a spontaneous autoimmune Th1-mediated destruction of pancreatic islet cells, have low levels of iNKT cells that are deficient in Th2 cytokines [103-105]. In addition, patients with Type I diabetes, including identical twin sets, had fewer invariant iNKT cells, which produced less Th2 cytokines than their nondiabetic siblings [97]. Other autoimmune diseases have been associated with low levels of iNKT cells. Mouse models for human systemic lupus erythematosus (SLE), start to have lower number of iNKT cells at around three to four weeks of age and iNKTcells completely disappear at around 10 weeks of age, 
when SLE manifests itself $[98,99]$. Interestingly in transgenic mice with delayed reduction in NKT cells, had delayed onset of the disease development [98,99].

In humans several autoimmune diseases, such as systemic sclerosis [106], SLE [107], rheumatoid arthritis [108-110], and multiple sclerosis [111,112], have been also associated with low iNKT cell levels.

In another interesting paradigm, autoimmunity could be driven by iNKT cells by infectious agents. Primary biliary cirrhosis (PBC) is due to an immune-mediated destruction of the small bile ducts, that causes bile extravasation, chronic inflammation, and subsequent liver fibrosis. iNKT cells were required for the initiation of this disease in a mouse model and iNKT cell are increased in the liver of PBC patients compared to healthy controls $[113,114]$. Interestingly the vast majority of patients with PBC have anti-mitochondrial antibodies, which recognize an epitope of the mitochondrial PDCE2 enzyme that is particularly well conserved in a commensal bacterium Novosphingobium aromaticivorans, a strain of Sphingomonas. As Sphingomonas cell wall glycolipids can strongly activate iNKT cells, these studies suggest that iNKT cells may play a key role in the pathogenesis of PBC by promoting aberrant responses to Sphingomonas [113,114].

\section{3. iNKT Cells in Infectious Diseases}

iNKT cells have been shown to play a role against bacterial, viral, fungal and protozoal infections [1]. However, most of the studies conducted in mice have been done on Ja18-deficient (Ja18KO) mice that. have been recently shown not only to lack iNKT cells, but also to have a more pervasive immune disorder as they have deficits in rearrangements of approximately $60 \%$ of their Ja segments, all of those upstream from $\mathrm{J} \alpha 18$, likely the result of insertion of the gene encoding neomycin resistance during construction of the gene-deficient mouse strain. This finding raises an important caveat to assigning any defect in J $\alpha 18 \mathrm{KO}$ mice solely to the iNKT cell defect [115].

iNKT cells appear to be important in mice to fight Streptococcus pneumonia, which induces them to secrete IFN $\gamma$ and IL-17A. Moreover J $\alpha 18 \mathrm{KO}$ mice had higher bacterial levels in the lung and a lower survival rate compared to wild-type (WT) mice when infected with S. pneumonia [116]. Chlamydia trachomatis and C. muridarum have an antigen, whose structure is unknown, that is able to activate iNKT cells, hence, iNKT cells may be involved in this sexually transmitted infection, however the mechanism of such involvement has not been elucidated yet $[58,59,117]$. iNKT cells in a mice model were also important in Borrelia burgdorferi infection [118,119].

iNKT cells are important in fungal infections. Lung infections with Cryptococcus neoformans are associated with iNKT cells accumulation mediated $\mathrm{C}-\mathrm{C}$ motif chemokine-2 (CCL-2)/macrophage chemoattractant protein-1 (MCP-1). In mice, Th1 cytokines from iNKT cells are essential for C. neoformans clearance [120,121].

Based on animal models, iNKT cells seem to be important also for the immune response against some protozoan parasites, such as Leishmania major, L. donovani, and Trypanosome cruzi. iNKT cells play mainly a role in fighting Leishmania infections, whereas regulate excessive inflammation in Trypanosome cruzi [60,122-126].

iNKT cells are also important in mice model to fight viral infections, in particular herpes family viruses, such as mouse cytomegalovirus (MCMV), a b herpes virus, and genital herpes simplex virus (HSV)-2 infection with a still unclear mechanism [127-129]. In humans, the lack of iNKT cells is 
primarily linked to overwhelming viral infections. A fatal and a life-threatening infection developed after receiving the varicella vaccine were shown to be due an isolated defect in iNKT cells [130,131]. X-linked lymphoproliferative syndrome (XLP) patients have a mutation SAP. These patients do not have iNKT cells and die of uncontrolled Epstein-Barr virus (EBV) infection [27,29]. Moreover, iNKT cells are reduced in number and function in patients with active Mycobacterium tuberculosis infection [132].

\section{4. iNKT Cells and Cancer}

iNKT cells have been discovered while aGalCer was studied as an anticancer therapy and, since then, there has been accumulating evidence that iNKT cells play a major roles in tumor immunosurveillance. Indeed by comparing Ja18-deficient and CD1d-deficient mice with wild-type mice, iNKT cells seem to be important in tumor immunosurvelance in different tumor models, such as methylcholanthrene (MCA)-induced fibrosarcomas, in p53 deficiency, and in the transgenic adenocarcinoma of the mouse prostate (TRAMP) prostate cancer model [133-136]. CD4-CD8- iNKT cells and iNKT cell derived IFN $\gamma$ production are most likely responsible for this antitumorogenic activity, by activating NK cells [137,138]. Thus far, however it is not clear if iNKT cells can also control tumor by targeting the tumor directly or by blocking angiogenesis driven by CD1d-expressing tumor-associated macrophages [139].

In humans, iNKT cells are decreased in tumors such as lung, breast, colon, and melanoma head and neck squamous cell carcinomas, and those patients with higher levels of iNKT cells have a better prognosis [140-142]. In clinical trials using $\alpha$ GalCer alone or $\alpha$ GalCer-pulsed antigen-presenting cells showed that these treatments are overall safe and well tolerated. What appeared most effective was the combined transfer of autologus iNKTcells and $\alpha$ GalCer-pulsed dendritic cells in patients with lung and head and neck squamous cell carcinomas [143]. Not surprisingly, however, the simple administration of soluble $\alpha$ GalCer did not have any major clinical benefit, as we know that can also induce IL-4 production and anergy of iNKT cells [144].

\section{Conclusion}

iNKT cells are a very interesting subset of $\mathrm{T}$ cells that may bridge the innate and adaptive immune systems. Indeed, iNKT cells can mount specific responses to antigen with cytokine production and cytotoxic activity however their TCR evolved to recognize different glycolipid antigens in a conserved manner and to perform innate-like rather than adaptive functions. In the last decade numerous studies have shown their role in diseases in which the immune system play a major role, such as cancer, infectious diseases, autoimmune and allergic syndrome. Given the fact that they can produce rapidly large amount of cytokines when appropriately stimulated without a clonal expansion, they represent and interesting pharmacological target to modulate the immune response

\section{Acknowledgement}

NIH K12HD043245-06, NIH-K08 K08 AI089982-01A1 CTRC Junior Investigator Pilot Grant Program (JIPGP). This project was supported by Grant Number UL1-RR-024134 from the National 
Center for Research Resources. The content is solely the responsibility of the authors and does not necessarily represent the official views of the National Center for Research Resources or the National Institutes of Health.

\section{Conflicts of Interest}

The authors declare no conflict of interest.

\section{References}

1. Bendelac, A.; Savage, P.B.; Teyton, L. The biology of NKT cells. Annu. Rev. Immunol. 2007, 25, 297-336.

2. Exley, M.A.; Wilson, B.; Balk, S.P. Isolation and functional use of human NKT cells. In Current Protocols in Immunology; Coligan, J.E., Bierer, B.E., Margulies, D.H., Shevach, E.M., Strober, W., Eds.; Wiley: New York, NY, USA, 2010; Chapter 14, Unit 14.11.

3. Exley, M.A.; Lynch, L.; Varghese, B.; Nowak, M.; Alatrakchi, N.; Balk, S.P. Developing understanding of the roles of CD1d-restricted $\mathrm{T}$ cell subsets in cancer: reversing tumor-induced defects. Clin. Immunol. 2011, 140, 184-195.

4. Kronenberg, M.; Kinjo, Y. Infection, Autoimmunity, and glycolipids: T cells detect microbes through self-recognition. Immunity 2005, 22, 657-659.

5. McCarthy, C.; Shepherd, D.; Fleire, S.; Stronge, V.S.; Koch, M.; Illarionov, P.A.; Bossi, G.; Salio, M.; Denkberg, G.; Reddington, F.; et al. The length of lipids bound to human CD1d molecules modulates the affinity of NKT cell TCR and the threshold of NKT cell activation. J. Exp. Med. 2007, 204, 1131-1144.

6. Nguyen, K.D.; Vanichsarn, C.; Nadeau, K.C. Increased cytotoxicity of CD4+ invariant NKT cells against CD4+CD25hiCD127lo/- regulatory $\mathrm{T}$ cells in allergic asthma. Eur. J. Immunol. 2008, 38, 2034-2045.

7. Taniguchi, M.; Harada, M.; Kojo, S.; Nakayama, T.; Wakao, H. The regulatory role of Valpha14 NKT cells in innate and acquired immune response. Annu. Rev. Immunol. 2003, 21, 483-513.

8. Pellicci, D.G.; Patel, O.; Kjer-Nielsen, L.; Pang, S.S.; Sullivan, L.C.; Kyparissoudis, K.; Brooks, A.G.; Reid, H.H.; Gras, S.; Lucet, I.S.; et al. Differential recognition of CD1d-alpha-galactosyl ceramide by the V beta 8.2 and V beta 7 semi-invariant NKT T cell receptors. Immunity 2009, 31, 47-59.

9. Matulis, G.; Sanderson, J.P.; Lissin, N.M.; Asparuhova, M.B.; Bommineni, G.R.; Schumperli, D.; Schmidt, R.R.; Villiger, P.M.; Jakobsen, B.K.; Gadola, S.D. Innate-like control of human iNKT cell autoreactivity via the hypervariable CDR3beta loop. PLoS Biol. 2010, 8, e1000402.

10. Brigl, M.; Brenner, M.B. CD1: Antigen presentation and T cell function. Annu. Rev. Immunol. 2004, 22, 817-890.

11. Gadola, S.D.; Koch, M.; Marles-Wright, J.; Lissin, N.M.; Shepherd, D.; Matulis, G.; Harlos, K.; Villiger, P.M.; Stuart, D.I.; Jakobsen, B.K.; et al. Structure and binding kinetics of three different human CD1d-alpha-galactosylceramide-specific T cell receptors. J. Exp. Med. 2006, 203, 699-710. 
12. Brigl, M.; van den Elzen, P.; Chen, X.; Meyers, J.H.; Wu, D.; Wong, C.H.; Reddington, F.; Illarianov, P.A.; Besra, G.S.; Brenner, M.B.; et al. Conserved and heterogeneous lipid antigen specificities of CD1d-restricted NKT cell receptors. J. Immunol. 2006, 176, 3625-3634.

13. Florence, W.C.; Xia, C.; Gordy, L.E.; Chen, W.; Zhang, Y.; Scott-Browne, J.; Kinjo, Y.; Yu, K.O.; Keshipeddy, S.; Pellicci, D.G.; et al. Adaptability of the semi-invariant natural killer T-cell receptor towards structurally diverse CD1d-restricted ligands. EMBO J. 2009, 28, 3579-3590.

14. Borg, N.A.; Wun, K.S.; Kjer-Nielsen, L.; Wilce, M.C.; Pellicci, D.G.; Koh, R.; Besra, G.S.; Bharadwaj, M.; Godfrey, D.I.; McCluskey, J.; et al. CD1d-lipid-antigen recognition by the semiinvariant NKT T-cell receptor. Nature 2007, 448, 44-49.

15. Moody, D.B.; Zajonc, D.M.; Wilson, I.A. Anatomy of CD1-lipid antigen complexes. Nat. Rev. Immunol. 2005, 5, 387-399.

16. Porcelli, S.A.; Segelke, B.W.; Sugita, M.; Wilson, I.A.; Brenner, M.B. The CD1 family of lipid antigen-presenting molecules. Immunol. Today 1998, 19, 362-368.

17. Porcelli, S.A. The CD1 family: A third lineage of antigen-presenting molecules. Adv. Immunol. 1995, 59, 1-98.

18. Han, M.; Hannick, L.I.; DiBrino, M.; Robinson, M.A. Polymorphism of human CD1 genes. Tissue Antigens 1999, 54, 122-127.

19. De Libero, G.; Mori, L. Recognition of lipid antigens by T cells. Nat. Rev. Immunol. 2005, 5, 485-496.

20. Esteban, L.M.; Tsoutsman, T.; Jordan, M.A.; Roach, D.; Poulton, L.D.; Brooks, A.; Naidenko, O.V.; Sidobre, S.; Godfrey, D.I.; Baxter, A.G. Genetic control of NKT cell numbers maps to major diabetes and lupus loci. J. Immunol. 2003, 171, 2873-2878.

21. Sandberg, J.K.; Bhardwaj, N.; Nixon, D.F. Dominant effector memory characteristics, Capacity for dynamic adaptive expansion, and sex bias in the innate Valpha24 NKT cell compartment. Eur. J. Immunol. 2003, 33, 588-596.

22. Gourdy, P.; Araujo, L.M.; Zhu, R.; Garmy-Susini, B.; Diem, S.; Laurell, H.; Leite-de-Moraes, M.; Dy, M.; Arnal, J.F.; Bayard, F.; et al. Relevance of sexual dimorphism to regulatory T cells: estradiol promotes IFN-gamma production by invariant natural killer T cells. Blood 2005, 105, 2415-2420.

23. Sandberg, J.K.; Ljunggren, H.G. Development and function of CD1d-restricted NKT cells: Influence of sphingolipids, SAP and sex. Trends Immunol. 2005, 26, 347-349.

24. Jyonouchi, S.; Abraham, V.; Orange, J.S.; Spergel, J.M.; Gober, L.; Dudek, E.; Saltzman, R.; Nichols, K.E.; Cianferoni, A. Invariant natural killer T cells from children with versus without food allergy exhibit differential responsiveness to milk-derived sphingomyelin. J. Allergy Clin. Immun. 2011, 128, 102-109.

25. Gadue, P.; Morton, N.; Stein, P.L. The Src family tyrosine kinase Fyn regulates natural killer T cell development. J. Exp. Med. 1999, 190, 1189-1196.

26. Eberl, G.; Lowin-Kropf, B.; MacDonald, H.R. Cutting edge: NKT cell development is selectively impaired in Fyn- deficient mice. J. Immunol. 1999, 163, 4091-4094.

27. Nichols, K.E.; Hom, J.; Gong, S.Y.; Ganguly, A.; Ma, C.S.; Cannons, J.L.; Tangye, S.G.; Schwartzberg, P.L.; Koretzky, G.A.; Stein, P.L. Regulation of NKT cell development by SAP, the protein defective in XLP. Nat. Med. 2005, 11, 340-345. 
28. Chung, B.; Aoukaty, A.; Dutz, J.; Terhorst, C.; Tan, R. Signaling lymphocytic activation molecule-associated protein controls NKT cell functions. J. Immunol 2005, 174, 3153-3157.

29. Pasquier, B.; Yin, L.; Fondaneche, M.C.; Relouzat, F.; Bloch-Queyrat, C.; Lambert, N.; Fischer, A.; de Saint-Basile, G.; Latour, S. Defective NKT cell development in mice and humans lacking the adapter SAP, the X-linked lymphoproliferative syndrome gene product. J. Exp. Med. 2005, 201, 695-701.

30. Latour, S.; Veillette, A. The SAP family of adaptors in immune regulation. Semin Immunol. 2004, 16, 409-419.

31. Cen, O.; Ueda, A.; Guzman, L.; Jain, J.; Bassiri, H.; Nichols, K.E.; Stein, P.L. The adaptor molecule signaling lymphocytic activation molecule-associated protein (SAP) regulates IFNgamma and IL-4 production in V alpha 14 transgenic NKT cells via effects on GATA-3 and Tbet expression. J. Immunol. 2009, 182, 1370-1378.

32. Wang, L.; Carr, T.; Xiong, Y.; Wildt, K.F.; Zhu, J.; Feigenbaum, L.; Bendelac, A.; Bosselut, R. The sequential activity of Gata3 and Thpok is required for the differentiation of CD1d-restricted CD4+ NKT cells. Eur. J. Immunol. 2010, 40, 2385-2390.

33. Kim, P.J.; Pai, S.Y.; Brigl, M.; Besra, G.S.; Gumperz, J.; Ho, I.C. GATA-3 regulates the development and function of invariant NKT cells. J. Immunol. 2006, 177, 6650-6659.

34. Gordy, L.E.; Bezbradica, J.S.; Flyak, A.I.; Spencer, C.T.; Dunkle, A.; Sun, J.; Stanic, A.K.; Boothby, M.R.; He, Y.W.; Zhao, Z.; et al. IL-15 regulates homeostasis and terminal maturation of NKT cells. J. Immunol. 2011, 187, 6335-6345.

35. Yi, Z.; Stunz, L.L.; Bishop, G.A. TNF receptor associated factor 3 plays a key role in development and function of invariant natural killer T cells. J. Exp. Med. 2013, 210, 1079-1086.

36. Cohen, N.R.; Garg, S.; Brenner, M.B. Antigen Presentation by CD1 Lipids, T Cells, and NKT Cells in Microbial Immunity. Adv. Immunol. 2009, 102, 1-94.

37. Diana, J.; Brezar, V.; Beaudoin, L.; Dalod, M.; Mellor, A.; Tafuri, A.; von Herrath, M.; Boitard, C.; Mallone, R.; Lehuen, A. Viral infection prevents diabetes by inducing regulatory $\mathrm{T}$ cells through NKT cell-plasmacytoid dendritic cell interplay. J. Exp. Med. 2011, 208, 729-745.

38. Godo, M.; Sessler, T.; Hamar, P. Role of invariant natural killer T (iNKT) cells in systemic lupus erythematosus. Curr. Med. Chem. 2008, 15, 1778-1787.

39. Gyimesi, E.; Nagy, G.; Remenyik, E.; Sipka, S.; Zeher, M.; Biro, T.; Szegedi, A. Altered peripheral invariant natural killer $\mathrm{T}$ cells in atopic dermatitis. J. Clin. Immunol. 2011, 31, 864-872.

40. Jyonouchi, S.; Smith, C.L.; Saretta, F.; Abraham, V.; Ruymann, K.R.; ModayurChandramouleeswaran, P.; Wang, M.L.; Spergel, J.M.; Cianferoni, A. Invariant natural killer T cells in children with eosinophilic esophagitis. Clin. Exp. Allergy 2013, Doi: 10.1111/cea.12201.

41. Kawano, T.; Nakayama, T.; Kamada, N.; Kaneko, Y.; Harada, M.; Ogura, N.; Akutsu, Y.; Motohashi, S.; Iizasa, T.; Endo, H.; et al. Antitumor cytotoxicity mediated by ligand-activated human V alpha24 NKT cells. Cancer Res. 1999, 59, 5102-5105.

42. Lisbonne, M.; Diem, S.; de Castro Keller, A.; Lefort, J.; Araujo, L.M.; Hachem, P.; Fourneau, J.M.; Sidobre, S.; Kronenberg, M.; Taniguchi, M.; et al. Cutting edge: Invariant V alpha 14 NKT cells are required for allergen-induced airway inflammation and hyperreactivity in an experimental asthma model. J. Immunol. 2003, 171, 1637-1641. 
43. Rajavelu, P.; Rayapudi, M.; Moffitt, M.; Mishra, A. Significance of para-esophageal lymph nodes in food or aeroallergen-induced iNKT cell-mediated experimental eosinophilic esophagitis. Am. J. Physiol. Gastrointest Liver Physiol. 2012, 302, G645-G654.

44. Thomas, S.Y.; Lilly, C.M.; Luster, A.D. Invariant natural killer T cells in bronchial asthma. N. Engl. J. Med. 2006, 354, 2613-2616.

45. Yokote, H.; Miyake, S.; Croxford, J.L.; Oki, S.; Mizusawa, H.; Yamamura, T. NKT cell-dependent amelioration of a mouse model of multiple sclerosis by altering gut flora. Am. J. Pathol. 2008, 173, 1714-1723.

46. Vivier, E.; Ugolini, S.; Blaise, D.; Chabannon, C.; Brossay, L. Targeting natural killer cells and natural killer T cells in cancer. Nat. Rev. Immunol. 2012, 12, 239-252.

47. Brennan, P.J.; Tatituri, R.V.; Brigl, M.; Kim, E.Y.; Tuli, A.; Sanderson, J.P.; Gadola, S.D.; Hsu, F.F.; Besra, G.S.; Brenner, M.B. Invariant natural killer T cells recognize lipid self antigen induced by microbial danger signals. Nat. Immunol. 2011, 12, 1202-1211.

48. Fox, L.M.; Cox, D.G.; Lockridge, J.L.; Wang, X.; Chen, X.; Scharf, L.; Trott, D.L.; Ndonye, R.M.; Veerapen, N.; Besra, G.S.; et al. Recognition of lyso-phospholipids by human natural killer T lymphocytes. PLoS Biol. 2009, 7, e1000228.

49. Kawano, T.; Cui, J.; Koezuka, Y.; Toura, I.; Kaneko, Y.; Motoki, K.; Ueno, H.; Nakagawa, R.; Sato, H.; Kondo, E.; et al. CD1d-restricted and TCR-mediated activation of valpha14 NKT cells by glycosylceramides. Science 1997, 278, 1626-1629.

50. Brossay, L.; Chioda, M.; Burdin, N.; Koezuka, Y.; Casorati, G.; Dellabona, P.; Kronenberg, M. CD1d-mediated recognition of an alpha-galactosylceramide by natural killer $\mathrm{T}$ cells is highly conserved through mammalian evolution. J. Exp. Med. 1998, 188, 1521-1528.

51. Wang, J.; Li, Y.; Kinjo, Y.; Mac, T.T.; Gibson, D.; Painter, G.F.; Kronenberg, M.; Zajonc, D.M. Lipid binding orientation within CD1d affects recognition of Borrelia burgorferi antigens by NKT cells. Proc. Natl. Acad. Sci. USA 2010, 107, 1535-1540.

52. Kawasaki, S.; Moriguchi, R.; Sekiya, K.; Nakai, T.; Ono, E.; Kume, K.; Kawahara, K. The cell envelope structure of the lipopolysaccharide-lacking gram-negative bacterium Sphingomonas paucimobilis. J. Bacteriol. 1994, 176, 284-290.

53. Zajonc, D.M.; Cantu, C., 3rd; Mattner, J.; Zhou, D.; Savage, P.B.; Bendelac, A.; Wilson, I.A.; Teyton, L. Structure and function of a potent agonist for the semi-invariant natural killer $\mathrm{T}$ cell receptor. Nat. Immunol. 2005, 6, 810-818.

54. Koch, M.; Stronge, V.S.; Shepherd, D.; Gadola, S.D.; Mathew, B.; Ritter, G.; Fersht, A.R.; Besra, G.S.; Schmidt, R.R.; Jones, E.Y.; et al. The crystal structure of human CD1d with and without alpha-galactosylceramide. Nat. Immunol. 2005, 6, 819-826.

55. Kinjo, Y.; Wu, D.; Kim, G.; Xing, G.W.; Poles, M.A.; Ho, D.D.; Tsuji, M.; Kawahara, K.; Wong, C.H.; Kronenberg, M. Recognition of bacterial glycosphingolipids by natural killer $\mathrm{T}$ cells. Nature 2005, 434, 520-525.

56. Kinjo, Y.; Tupin, E.; Wu, D.; Fujio, M.; Garcia-Navarro, R.; Benhnia, M.R.; Zajonc, D.M.; BenMenachem, G.; Ainge, G.D.; Painter, G.F.; et al. Natural killer T cells recognize diacylglycerol antigens from pathogenic bacteria. Nat. Immunol. 2006, 7, 978-986. 
57. Kinjo, Y.; Illarionov, P.; Vela, J.L.; Pei, B.; Girardi, E.; Li, X.; Li, Y.; Imamura, M.; Kaneko, Y.; Okawara, A.; et al. Invariant natural killer T cells recognize glycolipids from pathogenic Grampositive bacteria. Nat. Immunol. 2011, 12, 966-974.

58. Jiang, J.; Karimi, O.; Ouburg, S.; Champion, C.I.; Khurana, A.; Liu, G.; Freed, A.; Pleijster, J.; Rozengurt, N.; Land, J.A.; et al. Interruption of CXCL13-CXCR5 axis increases upper genital tract pathology and activation of NKT cells following chlamydial genital infection. PLoS One 2012, 7, e47487.

59. Peng, Y.; Zhao, L.; Shekhar, S.; Liu, L.; Wang, H.; Chen, Q.; Gao, X.; Yang, X.; Zhao, W. The glycolipid exoantigen derived from Chlamydia muridarum activates invariant natural killer T cells. Cell. Mol. Immunol. 2012, 9, 361-366.

60. Amprey, J.L.; Im, J.S.; Turco, S.J.; Murray, H.W.; Illarionov, P.A.; Besra, G.S.; Porcelli, S.A.; Spath, G.F. A subset of liver NK T cells is activated during Leishmania donovani infection by CD1d-bound lipophosphoglycan. J. Exp. Med. 2004, 200, 895-904.

61. Chang, Y.J.; Kim, H.Y.; Albacker, L.A.; Lee, H.H.; Baumgarth, N.; Akira, S.; Savage, P.B.; Endo, S.; Yamamura, T.; Maaskant, J.; et al. Influenza infection in suckling mice expands an NKT cell subset that protects against airway hyperreactivity. J. Clin. Invest. 2011, 121, 57-69.

62. Fischer, K.; Scotet, E.; Niemeyer, M.; Koebernick, H.; Zerrahn, J.; Maillet, S.; Hurwitz, R.; Kursar, M.; Bonneville, M.; Kaufmann, S.H.; et al. Mycobacterial phosphatidylinositol mannoside is a natural antigen for CD1d-restricted T cells. Proc. Natl. Acad. Sci. USA 2004, 101, 10685-10690.

63. Symolon, H.; Schmelz, E.M.; Dillehay, D.L.; Merrill, A.H., Jr. Dietary soy sphingolipids suppress tumorigenesis and gene expression in 1,2-dimethylhydrazine-treated CF1 mice and ApcMin/+ mice. J. Nutr. 2004, 134, 1157-1161.

64. Karlsson, A.A.; Michelsen, P.; Odham, G. Molecular species of sphingomyelin: determination by high-performance liquid chromatography/mass spectrometry with electrospray and highperformance liquid chromatography/tandem mass spectrometry with atmospheric pressure chemical ionization. J. Mass Spectrom. 1998, 33, 1192-1198.

65. Sullards, M.C.; Lynch, D.V.; Merrill, A.H., Jr.; Adams, J. Structure determination of soybean and wheat glucosylceramides by tandem mass spectrometry. J. Mass Spectrom. 2000, 35, 347-353.

66. Vesper, H.; Schmelz, E.M.; Nikolova-Karakashian, M.N.; Dillehay, D.L.; Lynch, D.V.; Merrill, A.H., Jr. Sphingolipids in food and the emerging importance of sphingolipids to nutrition. J. Nutr. 1999, 129, 1239-1250.

67. Berra, B.; Colombo, I.; Sottocornola, E.; Giacosa, A. Dietary sphingolipids in colorectal cancer prevention. Eur. J. Cancer Prev. 2002, 11, 193-197.

68. Brigl, M.; Bry, L.; Kent, S.C.; Gumperz, J.E.; Brenner, M.B. Mechanism of CD1d-restricted natural killer T cell activation during microbial infection. Nat. Immunol. 2003, 4, 1230-1237.

69. Kronenberg, M. Toward an understanding of NKT cell biology: Progress and paradoxes. Annu. Rev. Immunol. 2005, 23, 877-900.

70. Cui, J.; Shin, T.; Kawano, T.; Sato, H.; Kondo, E.; Toura, I.; Kaneko, Y.; Koseki, H.; Kanno, M.; Taniguchi, M. Requirement for Valpha14 NKT cells in IL-12-mediated rejection of tumors. Science 1997, 278, 1623-1626. 
71. Kim, J.O.; Kim, D.H.; Chang, W.S.; Hong, C.; Park, S.H.; Kim, S.; Kang, C.Y. Asthma is induced by intranasal coadministration of allergen and natural killer T-cell ligand in a mouse model. J. Allergy Clin. Immunol. 2004, 114, 1332-1338.

72. Meyer, E.H.; Goya, S.; Akbari, O.; Berry, G.J.; Savage, P.B.; Kronenberg, M.; Nakayama, T.; DeKruyff, R.H.; Umetsu, D.T. Glycolipid activation of invariant T cell receptor+ NK T cells is sufficient to induce airway hyperreactivity independent of conventional CD4+ T cells. Proc. Natl. Acad. Sci. USA 2006, 103, 2782-2787.

73. Bendelac, A.; Hunziker, R.D.; Lantz, O. Increased interleukin 4 and immunoglobulin E production in transgenic mice overexpressing NK1 T cells. J. Exp. Med. 1996, 184, 1285-1293.

74. Akbari, O.; Stock, P.; Meyer, E.; Kronenberg, M.; Sidobre, S.; Nakayama, T.; Taniguchi, M.; Grusby, M.J.; DeKruyff, R.H.; Umetsu, D.T. Essential role of NKT cells producing IL-4 and IL13 in the development of allergen-induced airway hyperreactivity. Nat. Med. 2003, 9, 582-588.

75. Akbari, O.; Faul, J.L.; Hoyte, E.G.; Berry, G.J.; Wahlstrom, J.; Kronenberg, M.; DeKruyff, R.H.; Umetsu, D.T. CD4+ invariant T-cell-receptor+ natural killer T cells in bronchial asthma. N. Engl. J. Med. 2006, 354, 1117-1129.

76. Hammond, K.J.; Poulton, L.D.; Palmisano, L.J.; Silveira, P.A.; Godfrey, D.I.; Baxter, A.G. alpha/beta-T cell receptor (TCR)+CD4-CD8- (NKT) thymocytes prevent insulin-dependent diabetes mellitus in nonobese diabetic (NOD)/Lt mice by the influence of interleukin (IL)-4 and/or IL-10. J. Exp. Med. 1998, 187, 1047-1056.

77. Taniguchi, M.; Koseki, H.; Tokuhisa, T.; Masuda, K.; Sato, H.; Kondo, E.; Kawano, T.; Cui, J.; Perkes, A.; Koyasu, S.; et al. Essential requirement of an invariant V alpha $14 \mathrm{~T}$ cell antigen receptor expression in the development of natural killer T cells. Proc. Natl. Acad. Sci. USA 1996, 93, 11025-11028.

78. Mars, L.T.; Laloux, V.; Goude, K.; Desbois, S.; Saoudi, A.; Van Kaer, L.; Lassmann, H.; Herbelin, A.; Lehuen, A.; Liblau, R.S. Cutting edge: V alpha 14-J alpha 281 NKT cells naturally regulate experimental autoimmune encephalomyelitis in nonobese diabetic mice. J. Immunol. 2002, 168, 6007-6011.

79. Engelmann, P.; Farkas, K.; Kis, J.; Richman, G.; Zhang, Z.; Liew, C.W.; Borowiec, M.; Niewczas, M.A.; Jalahej, H.; Orban, T. Characterization of human invariant natural killer T cells expressing FoxP3. Int. Immunol. 2011, 23, 473-484.

80. Moreira-Teixeira, L.; Resende, M.; Devergne, O.; Herbeuval, J.P.; Hermine, O.; Schneider, E.; Dy, M.; Cordeiro-da-Silva, A.; Leite-de-Moraes, M.C. Rapamycin combined with TGF-beta converts human invariant NKT cells into suppressive Foxp3+ regulatory cells. J. Immunol. 2012, 188, 624-631.

81. Kim, H.J.; Hwang, S.J.; Kim, B.K.; Jung, K.C.; Chung, D.H. NKT cells play critical roles in the induction of oral tolerance by inducing regulatory $\mathrm{T}$ cells producing IL-10 and transforming growth factor beta, and by clonally deleting antigen-specific T cells. Immunology 2006, 118, 101-111.

82. Wang, Z.Y.; Kusam, S.; Munugalavadla, V.; Kapur, R.; Brutkiewicz, R.R.; Dent, A.L. Regulation of Th2 cytokine expression in NKT cells: Unconventional use of Stat6, GATA-3, and NFAT2. J. Immunol. 2006, 176, 880-888. 
83. Kaneko, Y.; Harada, M.; Kawano, T.; Yamashita, M.; Shibata, Y.; Gejyo, F.; Nakayama, T.; Taniguchi, M. Augmentation of Valpha14 NKT cell-mediated cytotoxicity by interleukin 4 in an autocrine mechanism resulting in the development of concanavalin A-induced hepatitis. J. Exp. Med. 2000, 191, 105-114.

84. Kawamura, T.; Takeda, K.; Kaneda, H.; Matsumoto, H.; Hayakawa, Y.; Raulet, D.H.; Ikarashi, Y.; Kronenberg, M.; Yagita, H.; Kinoshita, K.; et al. NKG2A inhibits invariant NKT cell activation in hepatic injury. J. Immunol. 2009, 182, 250-258.

85. Campos-Martin, Y.; Colmenares, M.; Gozalbo-Lopez, B.; Lopez-Nunez, M.; Savage, P.B.; Martinez-Naves, E. Immature human dendritic cells infected with Leishmania infantum are resistant to NK-mediated cytolysis but are efficiently recognized by NKT cells. J. Immunol. 2006, 176, 6172-6179.

86. Das, R.; Bassiri, H.; Guan, P.; Wiener, S.; Banerjee, P.P.; Zhong, M.C.; Veillette, A.; Orange, J.S.; Nichols, K.E. The adaptor molecule SAP plays essential roles during invariant NKT cell cytotoxicity and lytic synapse formation. Blood 2013, 121, 3386-3395.

87. Elkhal, A.; Pichavant, M.; He, R.; Scott, J.; Meyer, E.; Goya, S.; Geha, R.S.; Umetsu, D.T. CD1d restricted natural killer $\mathrm{T}$ cells are not required for allergic skin inflammation. J. Allergy Clin. Immunol. 2006, 118, 1363-1368.

88. Araujo, L.M.; Lefort, J.; Nahori, M.A.; Diem, S.; Zhu, R.; Dy, M.; Leite-de-Moraes, M.C.; Bach, J.F.; Vargaftig, B.B.; Herbelin, A. Exacerbated Th2-mediated airway inflammation and hyperresponsiveness in autoimmune diabetes-prone NOD mice: A critical role for CD1ddependent NKT cells. Eur. J. Immunol. 2004, 34, 327-335.

89. Smiley, S.T.; Kaplan, M.H.; Grusby, M.J. Immunoglobulin E production in the absence of interleukin-4-secreting CD1-dependent cells. Science 1997, 275, 977-979.

90. Yoshimoto, T.; Bendelac, A.; Hu-Li, J.; Paul, W.E. Defective IgE production by SJL mice is linked to the absence of CD4+, NK1.1+ T cells that promptly produce interleukin 4. Proc. Natl. Acad. Sci. USA 1995, 92, 11931-11934.

91. Umetsu, D.T.; DeKruyff, R.H. A role for natural killer T cells in asthma. Nat. Rev. Immunol. 2006, 6, 953-958.

92. Kim, E.Y.; Battaile, J.T.; Patel, A.C.; You, Y.; Agapov, E.; Grayson, M.H.; Benoit, L.A.; Byers, D.E.; Alevy, Y.; Tucker, J.; et al. Persistent activation of an innate immune response translates respiratory viral infection into chronic lung disease. Nat. Med. 2008, 14, 633-640.

93. Tupin, E.; Nicoletti, A.; Elhage, R.; Rudling, M.; Ljunggren, H.G.; Hansson, G.K.; Berne, G.P. CD1d-dependent activation of NKT cells aggravates atherosclerosis. J. Exp. Med. 2004, 199, 417-422.

94. Askenase, P.W.; Szczepanik, M.; Itakura, A.; Kiener, C.; Campos, R.A. Extravascular T-cell recruitment requires initiation begun by Valpha14+ NKT cells and B-1 B cells. Trends Immunol. 2004, 25, 441-449.

95. Lisbonne, M.; Leite-de-Moraes, M.C. Invariant Valpha14 NKT lymphocytes: a double-edged immuno-regulatory T cell population. Eur. Cytokine Netw. 2003, 14, 4-14.

96. Heller, F.; Fuss, I.J.; Nieuwenhuis, E.E.; Blumberg, R.S.; Strober, W. Oxazolone colitis, a Th2 colitis model resembling ulcerative colitis, is mediated by IL-13-producing NK-T cells. Immunity 2002, 17, 629-638. 
97. Simoni, Y.; Diana, J.; Ghazarian, L.; Beaudoin, L.; Lehuen, A. Therapeutic manipulation of natural killer (NK) T cells in autoimmunity: are we close to reality? Clin. Exp. Immunol. 2013, $171,8-19$.

98. Mieza, M.A.; Itoh, T.; Cui, J.Q.; Makino, Y.; Kawano, T.; Tsuchida, K.; Koike, T.; Shirai, T.; Yagita, H.; Matsuzawa, A.; et al. Selective reduction of V alpha 14+ NK T cells associated with disease development in autoimmune-prone mice. J. Immunol. 1996, 156, 4035-4040.

99. Zeng, D.; Lee, M.K.; Tung, J.; Brendolan, A.; Strober, S. Cutting edge: A role for CD1 in the pathogenesis of lupus in NZB/NZW mice. J. Immunol. 2000, 164, 5000-5004.

100. Sonoda, K.H.; Exley, M.; Snapper, S.; Balk, S.P.; Stein-Streilein, J. CD1-reactive natural killer T cells are required for development of systemic tolerance through an immune-privileged site. J. Exp. Med. 1999, 190, 1215-1226.

101. Faunce, D.E.; Sonoda, K.H.; Stein-Streilein, J. MIP-2 recruits NKT cells to the spleen during tolerance induction. J. Immunol. 2001, 166, 313-321.

102. Sonoda, K.H.; Faunce, D.E.; Taniguchi, M.; Exley, M.; Balk, S.; Stein-Streilein, J. NK T cellderived IL-10 is essential for the differentiation of antigen-specific $\mathrm{T}$ regulatory cells in systemic tolerance. J. Immunol. 2001, 166, 42-50.

103. Gombert, J.M.; Herbelin, A.; Tancrede-Bohin, E.; Dy, M.; Carnaud, C.; Bach, J.F. Early quantitative and functional deficiency of NK1+-like thymocytes in the NOD mouse. Eur. J. Immunol. 1996, 26, 2989-2998.

104. Gombert, J.M.; Tancrede-Bohin, E.; Hameg, A.; Leite-de-Moraes, M.C.; Vicari, A.; Bach, J.F.; Herbelin, A. IL-7 reverses NK1+ T cell-defective IL-4 production in the non-obese diabetic mouse. Int. Immunol. 1996, 8, 1751-1758.

105. Gombert, J.M.; Herbelin, A.; Tancrede-Bohin, E.; Dy, M.; Chatenoud, L.; Carnaud, C.; Bach, J.F. Early defect of immunoregulatory T cells in autoimmune diabetes. C R Acad. Sci. III 1996, 319, 125-129.

106. Sumida, T.; Sakamoto, A.; Murata, H.; Makino, Y.; Takahashi, H.; Yoshida, S.; Nishioka, K.; Iwamoto, I.; Taniguchi, M. Selective reduction of T cells bearing invariant V alpha 24J alpha Q antigen receptor in patients with systemic sclerosis. J. Exp. Med. 1995, 182, 1163-1168.

107. Kojo, S.; Adachi, Y.; Keino, H.; Taniguchi, M.; Sumida, T. Dysfunction of T cell receptor AV24AJ18+, BV11+ double-negative regulatory natural killer $\mathrm{T}$ cells in autoimmune diseases. Arthritis Rheum. 2001, 44, 1127-1138.

108. Kukreja, A.; Costi, G.; Marker, J.; Zhang, C.H.; Sinha, S.; Sun, Z.; Maclaren, N. NKT cell defects in NOD mice suggest therapeutic opportunities. J. Autoimmun. 2002, 19, 117-128.

109. Kukreja, A.; Maclaren, N.K. NKT cells and type-1 diabetes and the "hygiene hypothesis" to explain the rising incidence rates. Diabetes Technol. Ther. 2002, 4, 323-333.

110. Kukreja, A.; Cost, G.; Marker, J.; Zhang, C.; Sun, Z.; Lin-Su, K.; Ten, S.; Sanz, M.; Exley, M.; Wilson, B.; et al. Multiple immuno-regulatory defects in type-1 diabetes. J. Clin. Invest. 2002, 109, 131-40.

111. Illes, Z.; Kondo, T.; Newcombe, J.; Oka, N.; Tabira, T.; Yamamura, T. Differential expression of NK T cell V alpha 24J alpha Q invariant TCR chain in the lesions of multiple sclerosis and chronic inflammatory demyelinating polyneuropathy. J. Immunol. 2000, 164, 4375-4381. 
112. Gausling, R.; Trollmo, C.; Hafler, D.A. Decreases in interleukin-4 secretion by invariant CD4(-)CD8(-)V alpha 24J alpha Q $\mathrm{T}$ cells in peripheral blood of patientswith relapsingremitting multiple sclerosis. Clin. Immunol. 2001, 98, 11-17.

113. Mattner, J.; Savage, P.B.; Leung, P.; Oertelt, S.S.; Wang, V.; Trivedi, O.; Scanlon, S.T.; Pendem, K.; Teyton, L.; Hart, J.; et al. Liver autoimmunity triggered by microbial activation of natural killer T cells. Cell. Host Microbe 2008, 3, 304-315.

114. Kita, H.; Naidenko, O.V.; Kronenberg, M.; Ansari, A.A.; Rogers, P.; He, X.S.; Koning, F.; Mikayama, T.; Van De Water, J.; Coppel, R.L.; et al. Quantitation and phenotypic analysis of natural killer T cells in primary biliary cirrhosis using a human CD1d tetramer. Gastroenterology 2002, 123, 1031-1043.

115. Bedel, R.; Matsuda, J.L.; Brigl, M.; White, J.; Kappler, J.; Marrack, P.; Gapin, L. Lower TCR repertoire diversity in Traj18-deficient mice. Nat. Immunol. 2012, 13, 705-706.

116. Kawakami, K.; Yamamoto, N.; Kinjo, Y.; Miyagi, K.; Nakasone, C.; Uezu, K.; Kinjo, T.; Nakayama, T.; Taniguchi, M.; Saito, A. Critical role of Valpha14+ natural killer T cells in the innate phase of host protection against Streptococcus pneumoniae infection. Eur. J. Immunol. 2003, 33, 3322-3330.

117. Joyee, A.G.; Qiu, H.; Wang, S.; Fan, Y.; Bilenki, L.; Yang, X. Distinct NKT cell subsets are induced by different Chlamydia species leading to differential adaptive immunity and host resistance to the infections. J. Immunol. 2007, 178, 1048-1058.

118. Olson, C.M., Jr.; Bates, T.C.; Izadi, H.; Radolf, J.D.; Huber, S.A.; Boyson, J.E.; Anguita, J. Local production of IFN-gamma by invariant NKT cells modulates acute Lyme carditis. J. Immunol. 2009, 182, 3728-3734.

119. Lee, W.Y.; Moriarty, T.J.; Wong, C.H.; Zhou, H.; Strieter, R.M.; van Rooijen, N.; Chaconas, G.; Kubes, P. An intravascular immune response to Borrelia burgdorferi involves Kupffer cells and iNKT cells. Nat. Immunol. 2010, 11, 295-302.

120. Kawakami, K.; Kinjo, Y.; Uezu, K.; Yara, S.; Miyagi, K.; Koguchi, Y.; Nakayama, T.; Taniguchi, M.; Saito, A. Monocyte chemoattractant protein-1-dependent increase of V alpha 14 NKT cells in lungs and their roles in Th1 response and host defense in cryptococcal infection. J. Immunol. 2001, 167, 6525-6532.

121. Cohen, N.R.; Tatituri, R.V.; Rivera, A.; Watts, G.F.; Kim, E.Y.; Chiba, A.; Fuchs, B.B.; Mylonakis, E.; Besra, G.S.; Levitz, S.M.; et al. Innate recognition of cell wall beta-glucans drives invariant natural killer T cell responses against fungi. Cell. Host Microbe 2011, 10, 437-450.

122. Ishikawa, H.; Hisaeda, H.; Taniguchi, M.; Nakayama, T.; Sakai, T.; Maekawa, Y.; Nakano, Y.; Zhang, M.; Zhang, T.; Nishitani, M.; et al. CD4(+) v(alpha)14 NKT cells play a crucial role in an early stage of protective immunity against infection with Leishmania major. Int. Immunol. 2000, $12,1267-1274$.

123. Amprey, J.L.; Spath, G.F.; Porcelli, S.A. Inhibition of CD1 expression in human dendritic cells during intracellular infection with Leishmania donovani. Infect. Immun. 2004, 72, 589-592.

124. Duthie, M.S.; Kahn, M.; White, M.; Kapur, R.P.; Kahn, S.J. Critical proinflammatory and antiinflammatory functions of different subsets of CD1d-restricted natural killer $\mathrm{T}$ cells during Trypanosoma cruzi infection. Infect. Immun. 2005, 73, 181-192. 
125. Duthie, M.S.; Kahn, S.J. Treatment with alpha-galactosylceramide before Trypanosoma cruzi infection provides protection or induces failure to thrive. J. Immunol. 2002, 168, 5778-5785.

126. Duthie, M.S.; Wleklinski-Lee, M.; Smith, S.; Nakayama, T.; Taniguchi, M.; Kahn, S.J. During Trypanosoma cruzi infection CD1d-restricted NK T cells limit parasitemia and augment the antibody response to a glycophosphoinositol-modified surface protein. Infect. Immun. 2002, 70, 36-48.

127. Ashkar, A.A.; Rosenthal, K.L. Interleukin-15 and natural killer and NKT cells play a critical role in innate protection against genital herpes simplex virus type 2 infection. J. Virol. 2003, 77, 10168-10171.

128. Grubor-Bauk, B.; Simmons, A.; Mayrhofer, G.; Speck, P.G. Impaired clearance of herpes simplex virus type 1 from mice lacking CD1d or NKT cells expressing the semivariant $\mathrm{V}$ alpha 14-J alpha 281 TCR. J. Immunol. 2003, 170, 1430-1434.

129. Cornish, A.L.; Keating, R.; Kyparissoudis, K.; Smyth, M.J.; Carbone, F.R.; Godfrey, D.I. NKT cells are not critical for HSV-1 disease resolution. Immunol. Cell. Biol. 2006, 84, 13-19.

130. Levy, O.; Orange, J.S.; Hibberd, P.; Steinberg, S.; LaRussa, P.; Weinberg, A.; Wilson, S.B.; Shaulov, A.; Fleisher, G.; Geha, R.S.; et al. Disseminated varicella infection due to the vaccine strain of varicella-zoster virus, in a patient with a novel deficiency in natural killer $\mathrm{T}$ cells. J. Infect. Dis. 2003, 188, 948-953.

131. Banovic, T.; Yanilla, M.; Simmons, R.; Robertson, I.; Schroder, W.A.; Raffelt, N.C.; Wilson, Y.A.; Hill, G.R.; Hogan, P.; Nourse, C.B. Disseminated varicella infection caused by varicella vaccine strain in a child with low invariant natural killer $\mathrm{T}$ cells and diminished $\mathrm{CD} 1 \mathrm{~d}$ expression. J. Infect. Dis. 2011, 204, 1893-1901.

132. Kee, S.J.; Kwon, Y.S.; Park, Y.W.; Cho, Y.N.; Lee, S.J.; Kim, T.J.; Lee, S.S.; Jang, H.C.; Shin, M.G.; Shin, J.H.; et al. Dysfunction of natural killer $\mathrm{T}$ cells in patients with active Mycobacterium tuberculosis infection. Infect. Immun. 2012, 80, 2100-2108.

133. Smyth, M.J.; Godfrey, D.I. NKT cells and tumor immunity-a double-edged sword. Nat. Immunol. 2000, 1, 459-460.

134. Swann, J.B.; Uldrich, A.P.; van Dommelen, S.; Sharkey, J.; Murray, W.K.; Godfrey, D.I.; Smyth, M.J. Type I natural killer T cells suppress tumors caused by p53 loss in mice. Blood 2009, 113, 6382-6385.

135. Nowak, M.; Arredouani, M.S.; Tun-Kyi, A.; Schmidt-Wolf, I.; Sanda, M.G.; Balk, S.P.; Exley, M.A. Defective NKT cell activation by CD1d+ TRAMP prostate tumor cells is corrected by interleukin-12 with alpha-galactosylceramide. PLoS One 2010, 5, e11311.

136. Bellone, M.; Ceccon, M.; Grioni, M.; Jachetti, E.; Calcinotto, A.; Napolitano, A.; Freschi, M.; Casorati, G.; Dellabona, P. iNKT cells control mouse spontaneous carcinoma independently of tumor-specific cytotoxic T cells. PLoS One 2010, 5, e8646.

137. Swann, J.B.; Coquet, J.M.; Smyth, M.J.; Godfrey, D.I. CD1-restricted T cells and tumor immunity. Curr. Top. Microbiol. Immunol. 2007, 314, 293-323.

138. Crowe, N.Y.; Smyth, M.J.; Godfrey, D.I. A critical role for natural killer $\mathrm{T}$ cells in immunosurveillance of methylcholanthrene-induced sarcomas. J. Exp. Med. 2002, 196, 119-127. 
139. Song, L.; Asgharzadeh, S.; Salo, J.; Engell, K.; Wu, H.W.; Sposto, R.; Ara, T.; Silverman, A.M.; DeClerck, Y.A.; Seeger, R.C.; et al. Valpha24-invariant NKT cells mediate antitumor activity via killing of tumor-associated macrophages. J. Clin. Invest. 2009, 119, 1524-1536.

140. Tahir, S.M.; Cheng, O.; Shaulov, A.; Koezuka, Y.; Bubley, G.J.; Wilson, S.B.; Balk, S.P.; Exley, M.A. Loss of IFN-gamma production by invariant NK T cells in advanced cancer. J. Immunol. 2001, 167, 4046-4050.

141. Tachibana, T.; Onodera, H.; Tsuruyama, T.; Mori, A.; Nagayama, S.; Hiai, H.; Imamura, M. Increased intratumor Valpha24-positive natural killer $\mathrm{T}$ cells: A prognostic factor for primary colorectal carcinomas. Clin. Cancer Res. 2005, 11, 7322-7327.

142. Schneiders, F.L.; de Bruin, R.C.; van den Eertwegh, A.J.; Scheper, R.J.; Leemans, C.R.; Brakenhoff, R.H.; Langendijk, J.A.; Verheul, H.M.; de Gruijl, T.D.; Molling, J.W.; et al. Circulating invariant natural killer T-cell numbers predict outcome in head and neck squamous cell carcinoma: Updated analysis with 10-year follow-up. J. Clin. Oncol. 2012, 30, 567-570.

143. Motohashi, S.; Okamoto, Y.; Yoshino, I.; Nakayama, T. Anti-tumor immune responses induced by iNKT cell-based immunotherapy for lung cancer and head and neck cancer. Clin. Immunol. 2011, 140, 167-176.

144. Giaccone, G.; Punt, C.J.; Ando, Y.; Ruijter, R.; Nishi, N.; Peters, M.; von Blomberg, B.M.; Scheper, R.J.; van der Vliet, H.J.; van den Eertwegh, A.J.; et al. A phase I study of the natural killer T-cell ligand alpha-galactosylceramide (KRN7000) in patients with solid tumors. Clin. Cancer Res. 2002, 8, 3702-3709.

(C) 2013 by the authors; licensee MDPI, Basel, Switzerland. This article is an open access article distributed under the terms and conditions of the Creative Commons Attribution license (http://creativecommons.org/licenses/by/3.0/). 